\title{
A cadmium budget for the Lot-Garonne fluvial system (France)
}

\author{
Gérard Blanc, Yvon Lapaquellerie, Noèle Maillet \& Pierre Anschutz \\ Département de Géologie et Océanographie (D.G.O.), Université Bordeaux 1, UMR CNRS 5805 EPOC., Avenue \\ des Facultés, 33405 Talence cedex, France \\ E-mail: blanc@geocean.u-bordeaux.fr
}

Key words: pollution, cadmium budget, Lot-Garonne rivers

\begin{abstract}
Routine measurements of river discharge and total suspended sediment concentration (TSS) are combined with regular analyses for particulate and dissolved cadmium to produce a box model that allows us to propose a cadmium mass balance for the Lot-Garonne man-influenced river system $\left(8400 \mathrm{~km}^{2}\right)$. Nearly half the cadmium in the Garonne river is supplied by the tributary Lot river. Cadmium input onto the Lot river comprises wet deposition from the atmosphere, molecular diffusion at the sediment-water interface, surface-water runoff and discharge from the leaching of waste at a zinc refining plant. Approximately $85 \%$ of the cadmium in the Lot river is derived from anthropogenic origin. Cadmium in the industrial discharge is $80 \%$ dissolved and $20 \%$ in the particulate phase $(4.2$ and $1.1 \mathrm{t} \mathrm{yr}^{-1}$, respectively). Total inputs are estimated at $4.81 \mathrm{t} \mathrm{yr}^{-1}$ and $1.54 \mathrm{t} \mathrm{yr}^{-1}$ for the dissolved cadmium and for the particulate phase, respectively. Budgeting estimates an output onto the Garonne river of $0.54 \mathrm{t} \mathrm{yr}^{-1}$ for the dissolved cadmium (about $8 \%$ ) and $6.13 \mathrm{t} \mathrm{yr}^{-1}$ for the particulate cadmium (about 92\%) indicating that downstream sediment-associated cadmium fluxes are enhanced by the $4.27 \mathrm{t} \mathrm{yr}^{-1}$ removed from solution and the $0.32 \mathrm{t} \mathrm{yr}^{-1}$ remobilized by the erosion of sediment blanketing the Lot river bed. These figures are found to be comparable with those generated by a dilution model which suggests that $97 \%$ of dissolved cadmium is taken up by the particulate phase over $0.5 \mathrm{~km}$ downstream from the primary anthropogenic source.
\end{abstract}

\section{Introduction}

Although the Aquitaine basin is one of the least industrialised regions in France, the Lot-Garonne-Gironde fluvial system can be considered as a natural model for pollution in non-ferrous metals such as $\mathrm{Cd}, \mathrm{Zn}, \mathrm{Ba}$, As (Roux \& Simonet, 1987). Historically, chronic pollution has resulted from industrial and mining activities that started to develop in the late nineteenth century and in particular, cadmium, which has a high toxicity for biota, is considered as the major polluting metal of this fluvial system. Cadmium pollution was first recognised in 1979 within the framework of the 'National Observation Network' (Latouche, 1988) which documented the high cadmium content in the flesh of the Gironde oysters (up to $100 \mu \mathrm{g} \mathrm{g}^{-1}$ of dry matter). These concentrations are 10 times higher than those typically found in oysters from French non-industrial areas (Boutier, 1981) and reflect the high kinetics accumulation in oysters. As oysters are very sensitive to this pollution, the Marennes-Oleron oyster farming located ca. $30 \mathrm{~km}$ to the north of the mouth of the Gironde estuary is considered at risk (Jouanneau et al., 1993).

The primary source for present day cadmium pollution is probably attributed to leaching from the waste area of a now abandoned zinc ore manufacturing facility (Latouche, 1992). This plant was founded in 1840 and is located near Decazeville, a town on the RiouMort that tributes to the Lot river ca. $200 \mathrm{~km}$ upstream from the Lot-Garonne confluence. However, several large hydroelectric dams which were built from 1945 to 1960 in the upper reaches of the Lot valley, together with the 62 smaller storage structures located downstream from the Riou-Mort confluence, decrease the magnitude of winter and spring floods (Massio, 1976). This has resulted in significant sediment and cadmium accumulation in the lower reaches of the Lot river. Lapaquellerie et al. (1995) estimated that $0.47 \pm 0.9$ $\times 10^{6} \mathrm{~m}^{3}$ of sediment and about 200 tons of cadmium 
accumulated in the Lot valley between the Riou-Mort and Garonne river in 1991.

This paper aims to establish a macroscopic description of cadmium behaviour in the Lot-Garonne fluvial system $\left(8400 \mathrm{~km}^{2}\right)$ by using the annual (1996) flux of both the particulate and dissolved phases. By quantifying the contributions from the primary source (i.e. the Riou-Mort river) and the secondary source (i.e. the sediment-associated cadmium in the Lot river), together with internal transfert processes and the overall output, we propose a tentative cadmium budget for the Lot-Garonne study basin.

\section{Sampling and methods}

Because the Lot river is the major polluting tributary of the Garonne, and then of the Gironde, it was necessary to obtain a representative estimation of its total suspended sediment (TSS) fluxes. This was accomplished using a total of six sampling sites (Figure 1). Samples from Temple (Lot) were collected automatically using a Buhler PB-MOS sampler, whilst samples from the five remaining sites were collected manually. The automatic sampler collects a daily cumulative 1 1 sample consisting of 16 elementary samples. The frequency of TSS measurements and analyses for particulate and dissolved cadmium is reported in Table 1. Transverse and depth profiling was undertaken to test the representativeness of our local sampling at Temple and La Reole sites (cf. Lapaquellerie et al., 1996). At both sites, these tests showed that variations in TSS concentrations due to depth and distance from the bank did not exceed $6 \%$ and $2.3 \%$ during flood and base flows, respectively. TSS concentrations were determined using filtration (Whatmann GF/F, $0.70 \mu \mathrm{m}$ filters) and each sample set typically showed a standard deviation of $1.5 \%$ about the mean. The annual mean values of the TSS concentrations for each site are reported in Table 2.

The mean annual discharge (1996) for the Lot and Garonne rivers was calculated using the daily measurements undertaken by the autonomous port of Bordeaux and the hydrological office of Toulouse (see Table 2). The precision is generally about $5 \%$ for water flows higher than $40 \mathrm{~m}^{3} \mathrm{~s}^{-1}$.

Sediment-associated cadmium concentrations were determined from bulk suspended sediment samples retrieved by centrifuging between 500 and 10001 of water using a Wesfalia separator. The cadmium contamination from this equipment is much less than the analytical error which is about $5 \%$ (Etcheber \& Jouanneau, 1980).

The water samples were collected and filtered for cadmium analyses using a clean technique. Surfacewater samples were taken from a small rubber dinghy, by immersing a teflon sampler specially designed to avoid any contact with the atmosphere. This sampler holds a $100 \mathrm{~cm}^{3}$ acid-cleaned polypropylene vial. The water samples were immediately filtered through acid-cleaned ( $\varnothing 47 \mathrm{~mm}$ diameter, $0.45 \mu \mathrm{m}$ pore-size) Nuclepore polycarbonate membranes.

Triplicate analyses for the particulate and dissolved cadmium concentrations of individual samples were undertaken using a graphite furnace atomic absorption spectrometer. Particulate cadmium analyses required the complete dissolution of individual dried solid samples. The total digestion used by this study involved the dissolution of $30 \mathrm{mg}$ of each sample in 750 $\mu 1 \mathrm{HCl}(12 \mathrm{~N}), 2 \mathrm{ml} \mathrm{HF}(26 \mathrm{~N})$ and $250 \mu \mathrm{HNO}_{3}(14 \mathrm{~N})$ in small Teflon bombs. The bomb were then heated at $110^{\circ} \mathrm{C}$ for $2 \mathrm{~h}$, and after cooling, the digested solution was evaporated to dryness and the residue dissolved in $150 \mu \mathrm{l}$ concentrated $\mathrm{HNO}_{3}$. Each sample was left on a hotplate until the residue was completely dissolved and then brought to $5 \mathrm{ml}$ in a volumetric flask using double-deionized water. Prior to the determination of dissolved cadmium content, the samples were preconcentrated in a class 100 clean room by complexating with ammonium pyrrolidine dithiocarbamate/ diethylammonium diethyl dithiocarbamate (APDC/DDDC), extracting into freon and back extracting with $\mathrm{HNO}_{3}$ into deionized water (Danielsson et al., 1982). In the Riou-Mort tributary, dissolved concentrations were high enough to be analyzed directly, without preconcentration. Accuracy of the analyses was determined by comparisons to river sediment (CRM320) and water (SLRS3) international standards, and was within $5 \%$ for cadmium. The precision of the analyses, as determined from duplicate samples was generally $5 \%$ for cadmium at concentrations 10 times higher than the detection limit. The content of cadmium in solid phases is given in milligrams per $\mathrm{kg}$, whereas the dissolved cadmium content is given in nanograms per 1 . The results of the cadmium analysis for 79 suspended sediment and 99 water samples collected during year 1996 are reported in Tables 3 and 4.

\section{Results}

River discharge, total suspended sediment (TSS) and cadmium concentrations are the major parameters for 


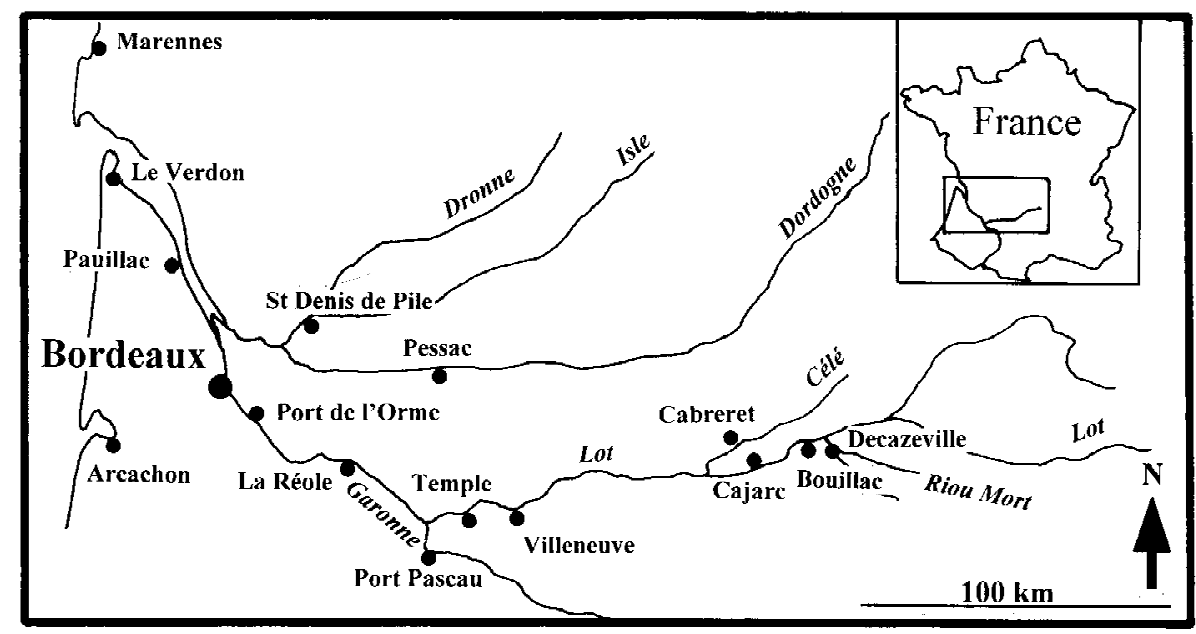

Figure 1. Sampling locations in the Garonne river, Lot river, and its tributaries (Riou-Mort, Célé), and also at the Verdon (estuary mouth).

Table 1. Location and sampling frequencies for the study sites, $\mathrm{x}$ and $\mathrm{y}$ are the coordinates in Lambert III projection, South Area

\begin{tabular}{|c|c|c|c|c|c|c|}
\hline \multirow[t]{2}{*}{ Sites } & \multirow[t]{2}{*}{ Map } & \multirow{2}{*}{$\begin{array}{l}\text { Location } \\
x / y\end{array}$} & \multirow{2}{*}{$\begin{array}{l}\text { Sampling } \\
\text { Type }\end{array}$} & \multicolumn{3}{|c|}{ Sampling strategy } \\
\hline & & & & TSS & dis.Cd & part.CD \\
\hline Riou-Mort & IGN $2238 \mathrm{~W}$ & $560.05 / 3241.09$ & manual & $8 \mathrm{yr}^{-1}$ & $8 \mathrm{yr}^{-1}$ & $8 \mathrm{yr}^{-1}$ \\
\hline Bouillac & IGN 2338 & $589.00 / 3253.45$ & manual & $8 \mathrm{yr}^{-1}$ & $6 \mathrm{yr}^{-1}$ & $5 \mathrm{yr}^{-1}$ \\
\hline Cajarc & IGN $2238 \mathrm{~W}$ & $560.05 / 3241.09$ & manual & $5 \mathrm{yr}^{-1}$ & $39 \mathrm{yr}^{-1}$ & $5 \mathrm{yr}^{-1}$ \\
\hline Temple sur Lot & IGN $1839 \mathrm{~W}$ & $453.55 / 3234.00$ & Automatic sampler & $365 \mathrm{yr}^{-1}$ & $18 \mathrm{yr}^{-1}$ & $18 \mathrm{yr}^{-1}$ \\
\hline Port Pascau & IGN $1739 \mathrm{E}$ & $439.07 / 3323.00$ & manual & $365 \mathrm{yr}^{-1}$ & $18 \mathrm{yr}^{-1}$ & $18 \mathrm{yr}^{-1}$ \\
\hline La Réole & IGN XV-37 (3-4) & $374.22 / 280.20$ & manual & $365 \mathrm{yr}^{-1}$ & $18 \mathrm{yr}^{-1}$ & $18 \mathrm{yr}^{-1}$ \\
\hline Le Verdon & IGN XIV-33 (1-2) & $334.62 / 62.18$ & manual & $4 \mathrm{yr}^{-1}$ & $5 \mathrm{yr}^{-1}$ & $6 \mathrm{yr}^{-1}$ \\
\hline
\end{tabular}

the estimation of dissolved and particulate matter fluxes. The river discharge can vary by factors of about 45 and 30 for the Garonne and Lot rivers, respectively. At the beginning of a flood such maximum changes in river discharge can usually be observed during a single day. In addition, the TSS concentrations change by a factor greater than one thousand between the flood and the lowest water level periods. At La Réole, the TSS concentration reached up to $1300 \mathrm{mg}^{-1}$ in December, whereas it fell down to $0.3 \mathrm{mg}^{-1}$ in September (Table 2). The annual mean value of TSS concentration varies spatially, increasing from $25 \mathrm{mg} \mathrm{l}^{-1}$ the Riou-Mort to $110 \mathrm{mg} \mathrm{l}^{-1}$ Cajarc. Conversely, the TSS concentration at Temple shows an annual mean value of $98 \mathrm{mg} \mathrm{l}^{-1}$. This lower value probably results from the settling of the suspended sediment into the numerous reservoirs. In 1996, the TSS concentration at Port-Pascau (Garonne) was approximately twice that of the downstream Lot. The changes in concentration of the particulate and dissolved cadmium show a temporal variability less than that of TSS concentration. Thus, it was not necessary to collect a sample every day, although the floods were sampled.

In 1996, the mean particulate cadmium concentrations decreased progressively from $460 \mathrm{mg} \mathrm{kg}^{-1}$ at the Riou-Mort to $12.5 \mathrm{mg} \mathrm{kg}^{-1}$ at Temple (Table 3). They were 10 times lower at Port-Pascau, and, consequently, a mean cadmium concentration of $2.6 \mathrm{mg} \mathrm{kg}^{-1}$ was determined at La Réole, downstream of the junction of the Lot and Garonne rivers. Because of the chlorinity increases in the Gironde estuary, the particulate cadmium concentrations reach a minimum mean value of $0.43 \mathrm{mg} \mathrm{kg}^{-1}$ at Le Verdon. The mean particulate cadmium concentration of $2.59 \mathrm{mg} \mathrm{kg}^{-1}$, determined in 1996 at La Réole, is comparable to that given by Elbaz-Poulichet (1988) for the Rhône river, and that given by Chiffoleau et al. (1997) for the Seine river (i.e. $2.8 \mathrm{mg} \mathrm{kg}^{-1}$ ), but much lower the 
Table 2. 1996 mean, maximum and minimum values for river discharge $\left(\mathrm{m}^{3} \cdot \mathrm{s}^{-1}\right)$ and TSS concentration $\left(\mathrm{mg} \cdot \mathrm{1}^{-1}\right)$ at each sampling site

\begin{tabular}{llccccccc}
\hline & & Riou-Mort & Bouillac & Cajarc & Temple & Port Pascau & La Réole & Le Verdon \\
\hline \multirow{3}{*}{ River discharge $\left(\mathbf{m}^{3} \mathbf{~ s}^{-1}\right)$} & mean & 3 & 80 & 89 & 171 & 637 & 808 & 1200 \\
& $\max$ & 35 & 431 & 480 & 922 & 3523 & 3928 & 4748 \\
& $\min$ & 8 & 18 & 22 & 30 & 32 & 85 & 170 \\
& & & & & & & & \\
TSS $\left(\mathbf{m g ~ l}^{-1}\right)$ & $\operatorname{mean}$ & 25.4 & 99.9 & 110.4 & 98.5 & 207.4 & 182.9 & 151.9 \\
& $\max$ & 81 & 196 & 205 & 390 & 1105 & 1297 & 313 \\
& $\min$ & 13 & 45 & 10 & 6 & 0.2 & 0.3 & 35 \\
\hline
\end{tabular}

Table 3. Particulate cadmium concentrations determined at each site in 1996

\begin{tabular}{|c|c|c|c|c|c|c|c|}
\hline & $\begin{array}{l}\text { Riou Mort } \\
\left(\mathrm{mg} \mathrm{kg}^{-1}\right)\end{array}$ & $\begin{array}{l}\text { Bouillac } \\
\left(\mathrm{mg} \mathrm{kg}^{-1}\right)\end{array}$ & $\begin{array}{l}\text { Cajarc } \\
\left(\mathrm{mg} \mathrm{kg}^{-1}\right)\end{array}$ & $\begin{array}{l}\text { Temple } \\
\left(\mathrm{mg} \mathrm{kg}^{-1}\right)\end{array}$ & $\begin{array}{l}\text { Port Pascau } \\
\left(\mathrm{mg} \mathrm{kg}^{-1}\right)\end{array}$ & $\begin{array}{l}\text { La Réole } \\
\left(\mathrm{mg} \mathrm{kg}^{-1}\right)\end{array}$ & $\begin{array}{l}\text { Le Verdon } \\
\left(\mathrm{mg} \mathrm{kg}^{-1}\right)\end{array}$ \\
\hline Jan 04 & & & & 11.3 & 0.69 & 2.53 & \\
\hline Jan 12 & & & & 15.2 & 0.34 & 2.34 & \\
\hline Jan 24 & & & & 16.1 & 0.33 & 1.91 & \\
\hline Jan 28 & & & & & & & 0.56 \\
\hline Feb 5 & & & & 15.9 & 0.74 & 1.47 & \\
\hline Feb 28 & & & & 12.3 & 1.32 & 1.58 & \\
\hline Mar 28 & & & & 10.4 & 1.24 & 2.34 & \\
\hline Apr 17 & 484 & 17.3 & 23.1 & & & & \\
\hline Apr 29 & & & & 16.0 & 1.2 & 3.6 & \\
\hline May 16 & & & & & & & 0.94 \\
\hline May 23 & & & & 10.8 & 1.31 & 3.52 & \\
\hline May 24 & 504 & 29.3 & 17.1 & & & & \\
\hline Jun 10 & & & & & & & 0.48 \\
\hline Jun 28 & 767 & & & 7.7 & 1.59 & 2.34 & \\
\hline Jul 10 & 350 & 22.5 & 26.7 & & & & \\
\hline Jul 18 & & & & 8.1 & 1.69 & 2.45 & \\
\hline Aug 28 & & & & 13.6 & 1.39 & 2.33 & \\
\hline Sep 02 & 244 & & & & & & \\
\hline Sep 06 & & & & & & & 0.21 \\
\hline Sep 10 & 689 & 29.9 & 21.7 & & & & \\
\hline Sep 26 & & & & 16.9 & 1.67 & 3.02 & \\
\hline Oct 08 & & & & 16.9 & 2.29 & 3.8 & \\
\hline Oct 15 & & & & & & & 0.18 \\
\hline Oct 28 & 286 & & & 10.2 & 2.56 & 2.22 & \\
\hline Nov 07 & & & & 7.4 & 1.15 & 3.3 & \\
\hline Nov 22 & & & & 12.1 & 1.86 & 2.01 & 0.21 \\
\hline Dec 04 & 386 & 33.1 & 14.5 & & & & \\
\hline Dec 10 & & & & 14.6 & 2.44 & 3.1 & \\
\hline Dec 19 & & & & 9.4 & 2.13 & 2.17 & \\
\hline Dec 23 & 432 & & & & & & \\
\hline Mean value & 460 & 26.4 & 20.6 & 12.5 & 1.44 & 2.59 & 0.43 \\
\hline
\end{tabular}


Table 4. Dissolved cadmium concentrations determined at each site in 1996

\begin{tabular}{|c|c|c|c|c|c|c|c|}
\hline & $\begin{array}{l}\text { Riou-Mort } \\
\left(\mathrm{ng} \mathrm{l}^{-1}\right)\end{array}$ & $\begin{array}{l}\text { Bouillac } \\
\left(\mathrm{ng} \mathrm{l}^{-1}\right)\end{array}$ & 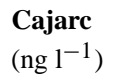 & $\begin{array}{l}\text { Temple } \\
\left(\mathrm{ng} 1^{-1}\right)\end{array}$ & $\begin{array}{l}\text { Port Pascau } \\
\left(\mathrm{ng}^{-1}\right)\end{array}$ & $\begin{array}{l}\text { La Réole } \\
\left(\mathrm{ng} 1^{-1}\right)\end{array}$ & $\begin{array}{l}\text { Le Verdon } \\
\left(\operatorname{ng~}^{-1}\right)\end{array}$ \\
\hline Jan 04 & & & 340 & 65 & 16 & 29 & \\
\hline Jan 12 & & & 134 & 48 & 48 & 33 & \\
\hline Jan 24 & & & 420 & 72 & 48 & 28 & \\
\hline Jan 28 & & & & & & & 385 \\
\hline Feb 5 & & & 532 & 97 & 49 & 64 & \\
\hline Feb 28 & & & 158 & 105 & 54 & 42 & \\
\hline Mar 28 & & & 245 & 64 & 58 & 95 & \\
\hline Apr 17 & 25000 & 139 & 593 & & & & \\
\hline Apr 29 & & & 169 & 43 & 32 & 88 & \\
\hline May 23 & & & 433 & 15 & 24 & 59 & \\
\hline May 24 & 25600 & 975 & 150 & & & & \\
\hline Jun 03 & & & 176 & & & & \\
\hline Jun 04 & & & 134 & & & & \\
\hline Jun 10 & & & & & & & 481 \\
\hline Jun 28 & 49800 & 810 & & 255 & 56 & 200 & \\
\hline Jul 10 & 34300 & & 346 & & & & \\
\hline Jul 18 & & & 628 & 230 & 120 & 185 & \\
\hline Aug 26 & & & 245 & & & & \\
\hline Aug 27 & & & 284 & & & & \\
\hline Aug 28 & & & 179 & 110 & 110 & 315 & \\
\hline Sep 02 & & & 534 & & & & \\
\hline Sep 03 & & & 157 & & & & \\
\hline Sep 04 & & & 608 & & & & \\
\hline \multicolumn{8}{|l|}{ Sep 06} \\
\hline Sep 10 & 80300 & 1860 & & & & & 467 \\
\hline Sep 26 & & & 303 & 20 & 64 & 52 & \\
\hline Oct 08 & & & 252 & 210 & 83 & 32 & \\
\hline Oct 15 & & & & & & & 320 \\
\hline Oct 28 & 16500 & & 128 & 240 & 45 & 41 & \\
\hline Nov 07 & & & 640 & 35 & 87 & 34 & \\
\hline Nov 14 & & & 635 & 94 & 19 & 38 & \\
\hline Nov 22 & & & & & & & 245 \\
\hline Dec 04 & 67280 & 1135 & 325 & & & & \\
\hline Dec 10 & & & 436 & 110 & 70 & 44 & \\
\hline Dec 19 & & & & 87 & 99 & 32 & \\
\hline Dec 23 & 53600 & 1230 & & & & & \\
\hline Mean value & 44048 & 1025 & 340 & 106 & 60 & 78 & 380 \\
\hline
\end{tabular}

$32 \mathrm{mg} \mathrm{kg}^{-1}$ given by Van der Weijden et al. (1989) for the Rhine. However, Idlafkih et al. (1995) gave a value of $4.9 \mathrm{mg} \mathrm{kg}^{-1}$ for the Seine river.

The dissolved cadmium concentration in 1996 averaged $44000 \mathrm{ng} \mathrm{l}^{-1}$ in the Riou-Mort (Table 4). This high content rapidly decreased downstream and reached a value of $106 \mathrm{ng} \mathrm{l}^{-1}$ at Temple. The mean dissolved cadmium concentrations at the Garonne river sites in 1996 were slightly lower, and thereafter increased by a factor of four (i.e. $380 \mathrm{ng} \mathrm{l}^{-1}$ ) at Le Verdon, where the salinity ranged from 14 to $24 \%$. An average value of $400 \mathrm{ng} \mathrm{l}^{-1}$ was previously determined for a comparable salinity range (Jouanneau et al., 1990), although Kraepiel et al. (1997) meas- 


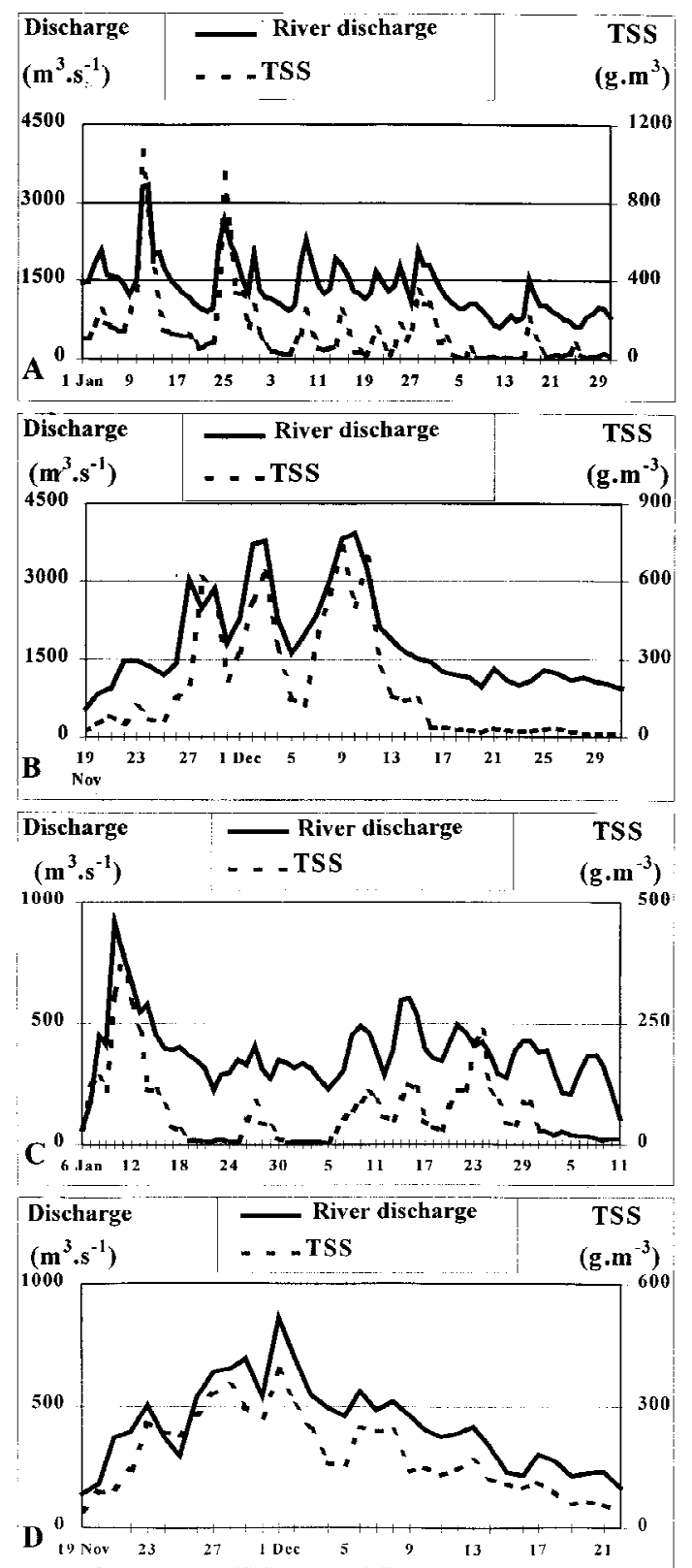

Figure 2. Temporal variations in 1996 peak discharge and TSS concentrations for the Garonne (A-B) and Lot (C-D) rivers.

ured values three times lower in February 1994 when high floods occurred. The mean concentration of the dissolved cadmium at La Réole, endpoint of the fresh water before the Gironde estuary, was $78 \mathrm{ng}^{-1}$. This value is higher than the world average (i.e. $20 \mathrm{ng} \mathrm{l}^{-1}$ ) estimated for river water (Martin \& Whitfield, 1983), and is comparable to that of the Mississippi river (i.e. $90 \mathrm{ng} \mathrm{l}^{-1}$ ) (Trefry \& Presley, 1976). The Cd concentra- tion of $78 \mathrm{ng}^{-1}$ for the Garonne is, however, higher than values measured in other major French rivers. In the Seine, Idlafkih et al. (1995) and Chiffoleau et al. (1997) gave values of $27 \mathrm{ng} \mathrm{l}^{-1}$ and $26 \mathrm{ng} \mathrm{l}^{-1}$, respectively. These values for the Seine are similar to those in the Rhine river (Elbaz-Poulichet, 1988), whereas a value of $48 \mathrm{ng} \mathrm{l}^{-1}$ was given by Valenta et al. (1984) for the Rhône river.

Minimum discharge values of 1500 and $500 \mathrm{~m}^{3} \mathrm{~s}^{-1}$ were used to identify a total of 45 and 19 flood days during 1996 for the Garonne and Lot rivers, respectively. The maximum values for the river water flows and the TSS concentrations were observed in JanuaryFebruary and November-December (Figure 2). Note that the higher TSS concentrations correspond to the higher river water flows, as previously recorded for numerous rivers (Meybeck, 1992). The river water flow data were recorded for the 1973-1996 period at Temple (Lot) and for the 1959-1996 period at La Réole (Garonne), and gave mean respective values of 160 and $640 \mathrm{~m}^{3} \mathrm{~s}^{-1}$. These values are comparable to those determined in 1996: $170 \mathrm{~m}^{3} \mathrm{~s}^{-1}$ and $810 \mathrm{~m}^{3} \mathrm{~s}^{-1}$, respectively. The mean discharge estimated for 1996 is, therefore, representative of the longer term hydrology of the study basin.

\section{Discussion}

As the frequency of TSS sampling is high, the quantification of the annual TSS fluxes $\left(F_{T S S}\right)$ in the Lot-Garonne system is based on the assumption that the TSS concentration remained constant between two consecutive samples (i.e. day after day). Thus, the annual $F_{T S S}$ are defined as the sum over 365 days of the following products (Meybeck, 1992):

$$
F_{T S S}=\Sigma_{1}^{365} Q_{\text {riv }} \cdot C_{T S S},
$$

where $Q_{\text {riv }}$ is the daily mean river water discharge and $\mathrm{C}_{\mathrm{TSS}}$ is the measured TSS concentration for each day. Considering the errors due to the sampling and analytical methods and those deriving from the Qriv determination, the precision is about $15 \%$ for the $F_{\text {TSS }}$ at Temple (Lot), Port Pascau and La Reole (Garonne).

As the daily mean TSS fluxes are well known, the annual particulate cadmium fluxes $\left(F_{\text {partCd }}\right)$ can be estimated from the assumption of the constant concentration given by Meybeck et al. (1994) as follows:

$$
F_{\text {partCd }}=\Sigma_{1}^{365} F_{\mathrm{TSS}} \cdot C_{\text {partCd}},
$$

where $F_{\mathrm{TSS}}$ is the daily mean TSS fluxes, $C_{\text {partCd }}$ is the particulate $\mathrm{Cd}$ concentration which is considered as a constant between each sampling episode. 
Table 5. 1996 river discharge and cadmium flux estimates for Temple (downstream Lot river), and percentage of cadmium delivered by the Lot to the Garonne river

\begin{tabular}{lc}
\hline & 1996 \\
\hline River discharge $\left(\mathrm{m}^{3} \mathrm{~s}^{-1}\right)$ & 171 \\
TSS flux $\left(10^{6} \mathrm{t} \mathrm{yr}^{-1}\right)$ & 0.531 \\
Dis. Cd flux $\left(\mathrm{t} \mathrm{yr}^{-1}\right)$ & 0.54 \\
Part. Cd flux $\left(\mathrm{t} \mathrm{yr}^{-1}\right)$ & 6.13 \\
Total Cd flux $\left(\mathrm{t} \mathrm{yr}^{-1}\right)$ & 6.67 \\
& \\
Lot river contribution $(\%)$ & 48
\end{tabular}

Because the annual variability of the river discharge is well established, the mean annual dissolved cadmium flux $\left(F_{\mathrm{disCd}}\right)$ was calculated using the weighted volume concentrations (Meybeck et al., 1994) as follows:

$$
F_{\mathrm{disCd}}=Q^{\prime} .(\Sigma Q i . C i / \Sigma Q i)
$$

where $Q^{\prime}$ is the annual water discharge, $C i$ is the dissolved cadmium concentration in a sample (i), and $Q i$ is the instantaneous river water flow measured at the time when the sample (i) was collected.

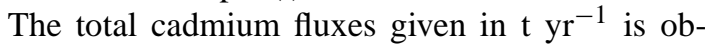
tained by the summation of the $F_{\text {partCd }}$ and $F_{\text {disCd }}$. These calculated fluxes are reported in Table 5. The results calculated for 1996 show that about $48 \%$ of cadmium flux through the Garonne is contributed by the Lot river. This result is comparable to others obtained since 1990 (Lapaquellerie et al., 1996). Our results also show that $90 \%$ of the cadmium output from the Lot is in the particulate phase. In order to define roughly the internal reactivity in the Lot river, it is useful to compare the cadmium output with the input onto this fluvial system.

\section{Sources of cadmium}

The annual atmospheric cadmium flux (1994) was estimated by determining the cadmium concentration of rain water collected by two rain gauges installed at Temple (downstream Lot) and at Castelnau Lassout (upstream Lot) (Figure 1). These measurements gave values averaging $37 \mathrm{ng}^{-1}$ at Castelnau Lassout and $39 \mathrm{ng}^{-1}$ at Temple for the cadmium concentrations, and 3.5 and $2 \mathrm{ng} \mathrm{cm}^{-2} \mathrm{yr}^{-1}$ for the cadmium fluxes. Maneux et al. (1998) reported annual cadmium fluxes of $9 \mathrm{ng} \mathrm{cm}-2 \mathrm{yr}^{-1}$ in 1994 from the rain deposition to the Arcachon Lagoon, which is a coastal zone in southwestern France, $60 \mathrm{~km}$ from Bordeaux. A maximum annual cadmium flux of 0.3

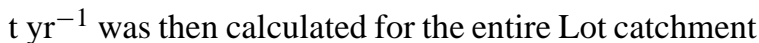
(i.e. $8400.10^{10} \mathrm{~cm}^{2}$ ). Because 1994 was the most humid year since 1996, the magnitude of the atmospheric cadmium flux probably leads to a small error in the atmospheric cadmium input for 1996. However, the annual water height at Castelnau Lassout was two times higher than that at Temple in 1994, while the cadmium concentrations were comparable in both sites.

The annual cadmium flux deriving from the natural run-off was estimated from a 1991-1996 database. Concentrations of dissolved and particulate cadmium were determined at Boisse Penchot, located $1 \mathrm{~km}$ upstream from the junction of the Riou-Mort and Lot rivers, and at Cabreret located $5 \mathrm{~km}$ from the junction of the Célé tributary and the Lot river (Figure 1). At Boisse Penchot, the mean concentrations of the dissolved and particulate cadmium were $65 \mathrm{ng} \mathrm{l}^{-1}$, and $1.2 \mathrm{mg} \mathrm{kg}^{-1}$, respectively. These values are comparable to those measured since 1990 at Port Pascau for the Garonne basin (i.e. $51 \mathrm{ng}^{-1}$ and $1.4 \mathrm{mg} \mathrm{kg}^{-1}$ ) (Lapaquellerie et al. , 1996). Taking a mean river water flow of $77 \mathrm{~m}^{3} \mathrm{~s}^{-1}$ in 1996, the dissolved cadmium flux was $0.16 \mathrm{t} \mathrm{yr}^{-1}$. Because the variability of the TSS concentrations is poorly documented at Boisse Penchot, we assume that the TSS flux at this site is equal to the difference between the TSS flux determined at Bouillac located $2 \mathrm{~km}$ downstream (i.e. $0.25210^{6}$

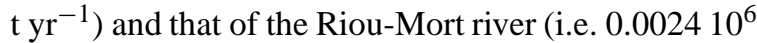

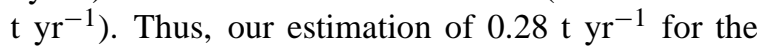
particulate cadmium flux must be considered as an approximate average value. At Cabreret, the concentrations show mean values of $98 \mathrm{ng} \mathrm{l}^{-1}$ for dissolved cadmium, $18.5 \mathrm{mg} \mathrm{kg}^{-1}$ for particulate cadmium, and $49 \mathrm{mg} \mathrm{l}^{-1}$ for TSS, leading to the calculated fluxes of $9 \mathrm{kt} \mathrm{yr}^{-1}$ for TSS, $0.16 \mathrm{t} \mathrm{yr}^{-1}$ for particulate and $0.02 \mathrm{t} \mathrm{yr}^{-1}$ for dissolved cadmium. Thus, the dissolved and the particulate run-off discharges from the Lot catchment are $0.18 \mathrm{t} \mathrm{yr}^{-1}$ and $0.44 \mathrm{t} \mathrm{yr}^{-1}$, respectively.

The next point is the estimation of the main cadmium source: the Riou-Mort. In 1996, two surveys of $24 \mathrm{~d}$ each were carried out using an automatic sampler. In addition to the values given in Tables 3 and 4, we calculated annual fluxes for TSS, dissolved and particulate cadmium of $2.4 \mathrm{kt} \mathrm{yr}^{-1}, 4.17 \mathrm{t} \mathrm{yr}^{-1}$ and 1.10 $\mathrm{t} \mathrm{yr}^{-1}$, respectively. Although the temporal variability 


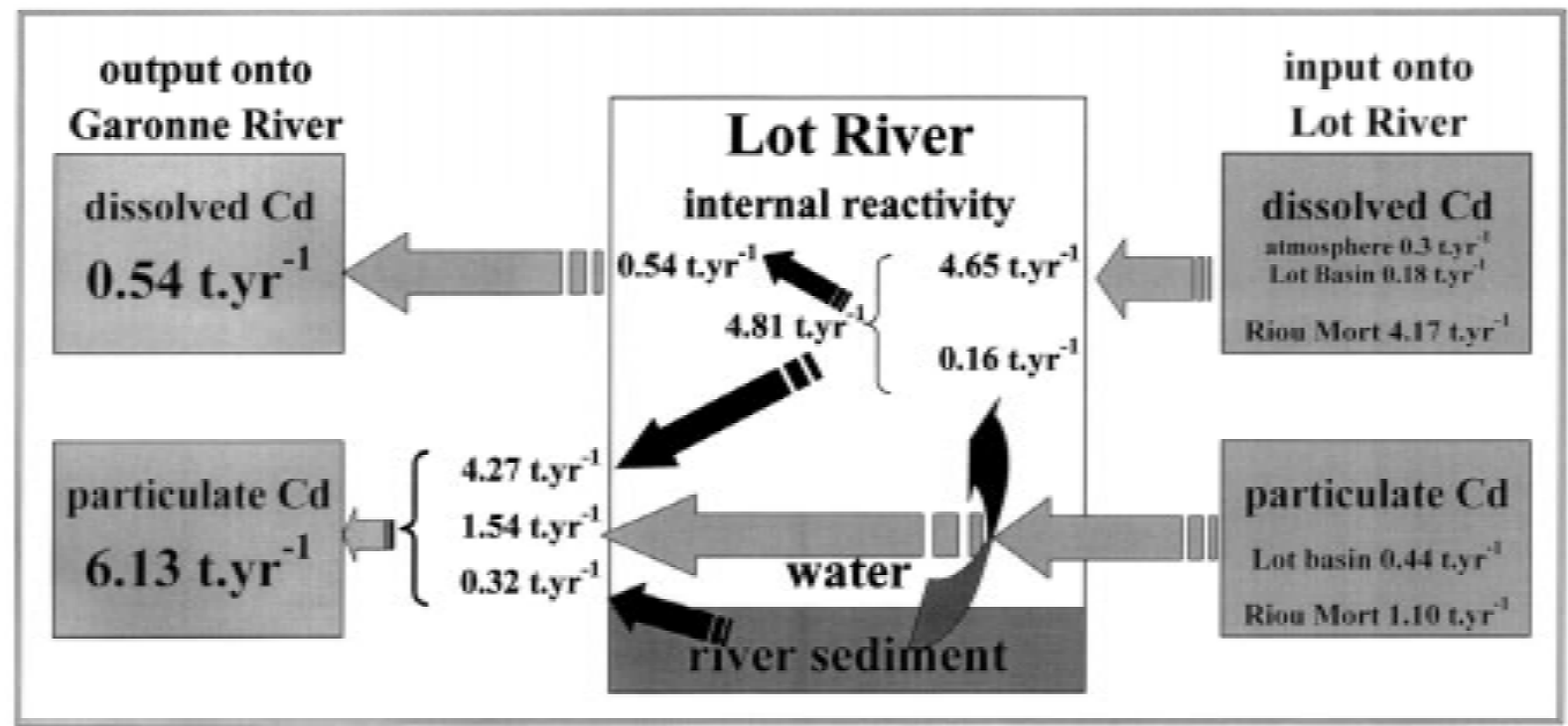

Figure 3. Box model of the cadmium budget for the Lot-Garonne study basin.

of the concentrations is underdocumented in comparison with that obtained at Temple, these results are comparable to those obtained from two short surveys in February and June 1994 made by the "Agence de l'Eau Adour-Garonne" (1995). Furthermore, we note that only about $20 \%$ of the cadmium is transported by the Riou-Mort river in particulate forms. Thus, the temporal variability of the TSS concentrations has a smaller influence on the estimation of the total cadmium input to the Lot river. From these results, we assume that the cadmium input is characterized by fluxes of $4.65 \mathrm{t} \mathrm{yr}^{-1}$ in dissolved form and $1.54 \mathrm{t} \mathrm{yr}^{-1}$ in particulate form. However, an additional source of dissolved cadmium needs to be evaluated: this is the molecular diffusion flux at the water-sediment interface. Two concentration-depth profiles for the dissolved cadmium were obtained from two sediment cores recovered in 1996 at Cajarc and Temple. If we assume that only vertical transport through interstitial waters is important, then the flux of a chemical constituent can be described by the Fick law. Using a corrected temperature diffusion coefficient of $3.310^{-6} \mathrm{~cm}^{2} \mathrm{~s}^{-1}$ for cadmium (Lerman, 1979), dissolved cadmium diffusion fluxes of $2510^{-6}$ and $9.210^{-6} \mathrm{ng} \mathrm{cm}^{-2} \mathrm{~s}^{-1}$ were computed from the concentration gradients obtained between the interstitial and the deep water at Cajarc and Temple, respectively. Two other cores recovered at the same sites in 1992 gave fluxes slightly higher, $4110^{-6}$ and $16.210^{-6} \mathrm{ng} \mathrm{cm}^{-2} \mathrm{~s}^{-1}$. The sediment surface within the Lot river channel between its confluences with the Riou-Mort and the Garonne was estimated at $22 \mathrm{~km}^{2}$ (Lapaquellerie et al., 1995). Thus, we obtain a rough estimate of $0.16 \mathrm{t} \mathrm{yr}^{-1}$ for the annual cadmium flux associated with molecular diffusion. Consequently, the dissolved cadmium input could be $4.81 \mathrm{t} \mathrm{yr}^{-1}$.

Since the dissolved cadmium output was 0.54

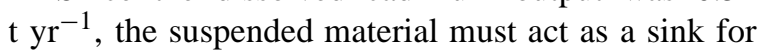
dissolved cadmium, which is removed from the solution (Figure 3). The magnitude of this removal is 4.27

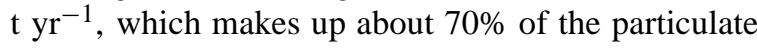
cadmium output. By adding $1.54 \mathrm{t}$ of particulate cadmium transported by the Lot river in 1996, we obtain a deficit of $0.32 \mathrm{t} \mathrm{yr}^{-1}$ for the particulate cadmium output. Note that the cadmium input is approximately equal to the output in 1996. This small deficit can be interpreted, however, in terms of cadmium mobilization removed from the Lot river sediment by erosion.

\section{Cadmium mass balance}

This result can be tested by a simple model that shows the change of the cadmium concentrations as a function of dilution from the Riou-Mort to the Gironde estuary. The dissolved concentrations are diluted by the progressive downstream increase in the river discharge for the Lot, whereas the dilution of the particulate concentrations is related to the TSS fluxes. Thus, it is convenient to use a framework in which dissolved cadmium and particulate cadmium are con- 


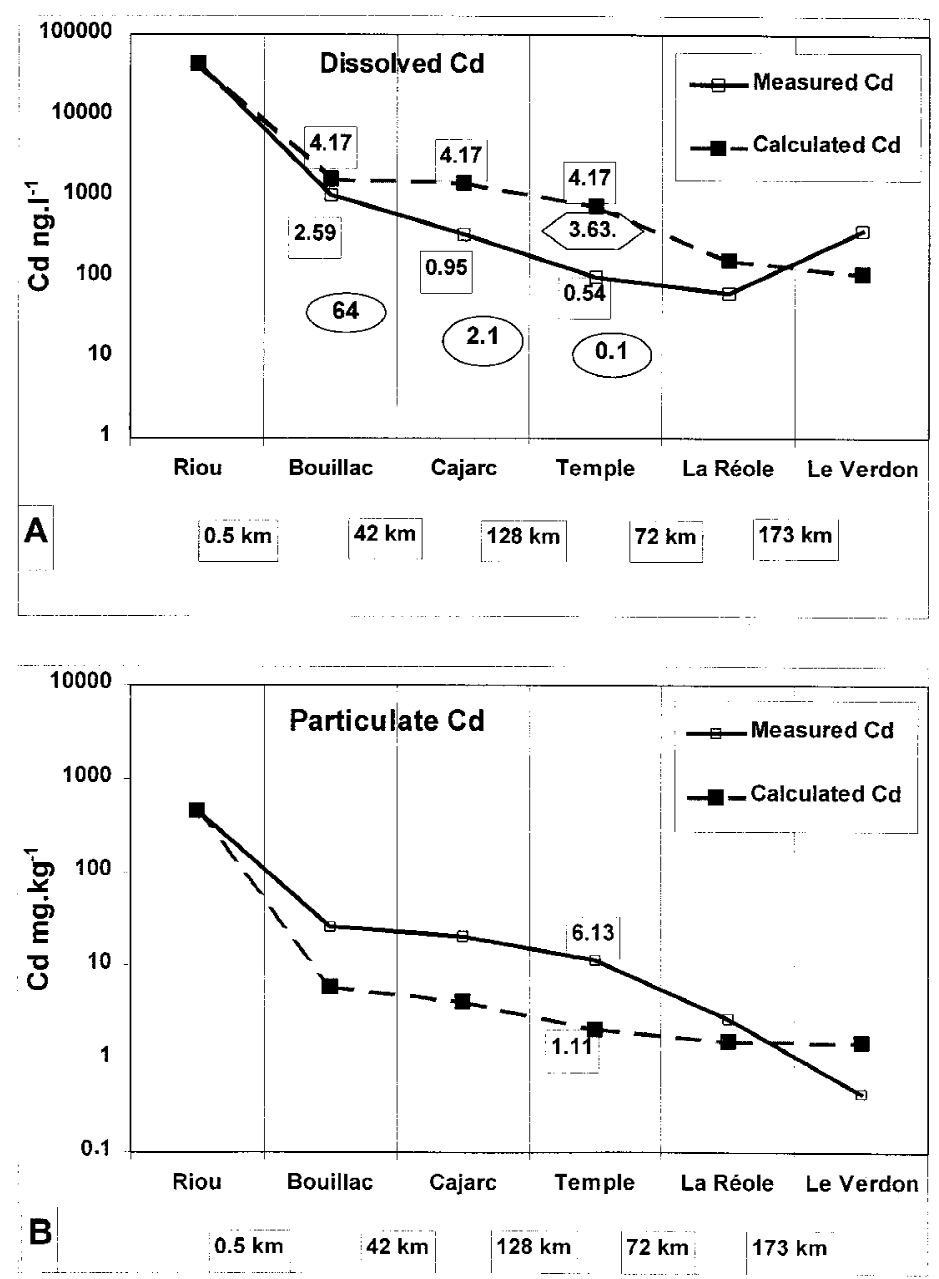

Figure 4. Dilution model for dissolved (A) and the particulate (B) cadmium concentrations. Numbers into open squares are in $\mathrm{tyr}^{-1}$, numbers in open circles are in $\mu \mathrm{g} \mathrm{m}^{-1} \mathrm{~s}^{-1}$.

sidered separately. The parameters for calculation are presented in Table 6, and the calculated concentrations are compared to those measured in Figure 4. This comparison shows that the calculated dissolved cadmium concentrations are higher than those measured from the Riou-Mort to La Réole, whereas the measured concentrations are higher than those calculated in the estuary. The pattern is reversed for the particulate cadmium. Qualitatively, Figure 4 shows that cadmium is removed from the solution between the Riou-Mort and La Réole, then the cadmium undergoes estuarine dissolved-particulate reactions which lead to its addition to the dissolved phase. The quantification of this addition cannot be assessed with accuracy because the cadmium output at the estuary mouth is not adequately documented in this study. Nevertheless, it is useful to look at the difference between the calculated and measured concentrations along the Lot river. From these concentrations, dissolved cadmium fluxes can be estimated for each sample site (Figure 4A). At Temple, the flux difference (e.g. $4.17 \mathrm{t} \mathrm{yr}^{-1}$ minus $0.54 \mathrm{t} \mathrm{yr}^{-1}$ ) yields a value of $3.63 \mathrm{t} \mathrm{yr}^{-1}$ which corresponds to the annual removal of the Riou-Mort dissolved cadmium input. By adding the cadmium input not taken into account in the dilution model (i.e. atmosphere, runoff, and diffusion inputs), we find $4.27 \mathrm{t} \mathrm{yr}^{-1}$, equal to the removal value determined in the box model. By considering the distance between each site along the Lot river, we deduced that the cadmium removal from solution decreases rapidly in the downstream direction, with a rate of $64 \mu \mathrm{g} \mathrm{m}^{-1} \mathrm{~s}^{-1}$ from the Riou-Mort junction to Bouillac $(0.5 \mathrm{~km}), 2.1 \mu \mathrm{g} \mathrm{m}^{-1} \mathrm{~s}^{-1}$ from 
Table 6. A comparison between measured and modelled cadmium concentrations for each sampling sites. Parameters used for the calculation of the dissolved and particulate concentrations resulting from the dilution of the Riou-Mort cadmium input. The calculated particulate cadmium concentrations are deduced from the dilution factor due to the additional TSS fluxes along the Lot river. The calculated dissolved cadmium concentrations are deduced from the dilution factor due to the additional river discharge along the Lot river

\begin{tabular}{|c|c|c|c|c|c|c|c|c|}
\hline & $\begin{array}{l}\text { TSS flux } \\
\left(10^{6} \mathrm{t} \mathrm{yr}^{-1}\right)\end{array}$ & $\begin{array}{l}\text { Dilution } \\
\text { factor }\end{array}$ & $\begin{array}{l}\text { measured } \\
\text { part. Cd } \\
\left(\mathrm{mg} \mathrm{kg}{ }^{-1}\right)\end{array}$ & $\begin{array}{l}\text { calculated } \\
\text { part. } \mathbf{C d} \\
\left.(\mathbf{m g ~ k g})^{-1}\right)\end{array}$ & $\begin{array}{l}\text { Discharge } \\
\left(\mathbf{m}^{3} \mathbf{s}^{-1}\right)\end{array}$ & $\begin{array}{l}\text { Dilution } \\
\text { factor }\end{array}$ & $\begin{array}{l}\text { measured } \\
\text { dis. Cd } \\
\left(\mathrm{ng} \mathrm{l}^{-1}\right)\end{array}$ & $\begin{array}{l}\text { calculated } \\
\text { dis. } \mathrm{Cd} \\
\mathrm{ng} \mathrm{l^{-1 }} \text { ) }\end{array}$ \\
\hline Riou-Mort & 0.0024 & & 460 & 460 & 3 & & 44048 & 44048 \\
\hline Bouillac & 0.252 & 77 & 26.4 & 6 & 80 & 27 & 1025 & 1652 \\
\hline Cajarc & 0.31 & 114 & 20.7 & 4.1 & 89 & 30 & 340 & 1485 \\
\hline Temple & 0.531 & 221 & 11.6 & 2.1 & 171 & 57 & 101 & 773 \\
\hline La Réole & 4.661 & 1942 & 2.69 & 1.53 & 808 & 269 & 64 & 164 \\
\hline Le Verdon & 5.75 & 2395 & 0.43 & 1.5 & 1200 & 400 & 380 & 110 \\
\hline
\end{tabular}

Bouillac to Cajarc $(42 \mathrm{~km})$ and $0.1 \mu \mathrm{g} \mathrm{m}^{-1} \mathrm{~s}^{-1}$ from Cajarc to Temple $(128 \mathrm{~km})$. Thus, $97 \%$ of dissolved cadmium input is absorbed by the suspended sediment within $0.5 \mathrm{~km}$ after the confluence of the Riou-Mort and the Lot. The magnitude of the removal from dissolved to particulate phases can also be estimated using the dilution model of the particulate cadmium (Figure 4B). The cadmium concentrations measured at Temple lead to a flux of $6.13 \mathrm{t} \mathrm{yr}^{-1}$. This particulate cadmium flux included four discrete discharges. They are the natural cadmium delivered by the Lot catchment (i.e. $0.44 \mathrm{t} \mathrm{yr}^{-1}$ ), the cadmium released from the sediment blanketing the Lot river bed (i.e. 0.32

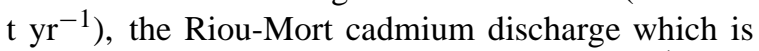
the value given by the dilution model $\left(1.11 \mathrm{t} \mathrm{yr}^{-1}\right)$, and the cadmium which is deduced to be removed from solution (4.26 $\mathrm{t} \mathrm{yr}^{-1}$ ). This value is clearly comparable to that determined using the box model. Thus, the budgeting approach developed in this study is efficient to describe the macroscpic behaviour of cadmium in the Lot-Garonne study basin.

\section{Conclusion}

The annual river discharge for the Lot-Garonne fluvial system during 1996 is representative of the longerterm mean. The flux estimates presented in this study are based upon regular high frequency measurement for a large study basin and algoritihms recommended by Meybeck et al. (1994). These algorithms are similar to those used for British rivers (Webb et al., 1997). Bearing this point in mind, the tentative budget produced by this study estimates that $48 \%$ of the cadmium flux in the Garonne river originates from the Lot river. The cadmium contribution from the Lot is about $90 \%$ particulate. This particulate flux comprises the particulate cadmium transported by the entire Lot catchment ( $\sim 25 \%$ ), the particulate cadmium removed from solution by exchange from dissolved to particulate phases $(\sim 70 \%)$, and the particulate cadmium mobilized from the sediment blanketing of the Lot bed $(\sim 5 \%)$. The cadmium input into the Lot river is $75 \%$ dissolved. The dissolved cadmium input overall includes wet atmospheric deposition $(\sim 6 \%)$, surface run-off of the Lot catchment $(\sim 4 \%)$, molecular diffusion at the watersurface interface $(\sim 3 \%)$, and the major anthropogenic source: the Riou-Mort tributary $(\sim 87 \%)$. Within a distance of $0.5 \mathrm{~km}$ from this anthropogenic source, about $97 \%$ of dissolved cadmium input is taken up by the suspended solid phase.

This study indicates that two areas of the LotGaronne study basin should be targeted by any future investigations of change in metal speciations between the particulate, dissolved and colloidal phases. These are between the Riou-Mort and Bouillac on the Lot river, and from La Réole to Bordeaux at the GaronneGironde fresh/salt water interface.

\section{Acknowledgements}

This study is a scientific contribution no 1271 from Bordeaux 1 University, D.G.O, UMR CNRS 5805 EPOC and from the 'IMPACTS' program of the 'GIS ECOBAG' (Groupement d'Intérêt Scientifique: Ecologie du Bassin Adour-Garonne). We wish to thank Roger Lohou, 'Président' of this GIS. Claude 
Latouche, Michel Roux and François Simonet, members of the scientific committee of the 'Agence de l'Eau Adour-Garonne' are also greatfully acknowledged. This work was supported by grants from 'l'Agence de l'eau Adour-Garonne' and 'le Ministère Français de l'Environnement'. We wish to thank R. $\mathrm{H}$. Meade and anonymous reviewers for their thoughtful comments and suggestions which greatly improved the form and the content of the paper. Effective and efficient guest editors are also greatfully acknowledged.

\section{References}

Agence de l'eau Adour-Garonne, 1995. Estimation des flux de cadmium et de zinc vehiculés par le Riou-Mort. Rapport interne février: $1-13$.

Boutier, B., 1981. Synthèse des résultats de la surveillance des micropolluants dans la matière vivante. Ministère de l'Environnement, Bulletin du Réseau National d'Observation. 17: 115-174.

Chiffoleau, J. F., D.Auger, E. Chartier \& I. Truquet, 1997. Identification et devenir des apports intra-estuariens de metaux-traces dans l'estuaire de la Seine. In Programme scientifique Seine-aval, Rapport 1996/FIN-3: 5-23.

Danielsson, L. G., B. Magnusson, S. Westerlund \& K. Zhang, 1982. Trace metal determination in estuarine waters by electrothermal AAS after extraction of dithiocarbonate complexes in freon. Anal. Chim. Acta. 144: 159-175.

Elbaz-Poulichet, F., 1988. Apports fluviatiles et estuariens de plomb, cadmium et cuivre aux océans, comparaisons avec l'apport atmosphérique. Thèse, Université Paris VI. 210pp.

Etcheber, H. \& J. M. Jouanneau, 1980. Comparison of the different methods for the recovery of suspended matter from estuarine waters deposition, filtration and centrifugation; consequences for the determination of some heavy metals. Estuar. Coast. mar. sc. II: 701-707.

Idlafkih, Z., D. Cossa \& M. Meybeck, 1995. Comportements des contaminants en trace dissous et particulaires (As, $\mathrm{Cd}, \mathrm{Cu}, \mathrm{Hg}$, $\mathrm{Pb}, \mathrm{Zn}$ ) dans la Seine. Hydroecol. Appl. 7: 127-150.

Jouanneau, J. M., B. Boutier, J. F. Chiffoleau, C. Latouche \& I Phillips, 1990. Cadmium in the Gironde fluvioestuarine system: behaviour and flow. Sci. Total Envir. 97/98: 465-469.

Jouanneau, J. M., Y. Lapaquellerie \& C. Latouche, 1993. Origin and pathways of Cd contamination in the Gironde estuary, Garonne river and tributaries. In J. P. Vernet (ed.), Environment Contamination. Elsevier: 373-389.

Kraepiel, A. M. L., J. F. Chiffoleau, J-M. Martin \& F. M. M. Morel, 1997. Geochemistry of trace metals in the Gironde estuary. Geochimica et Cosmochimica Acta.61: 1421-1436.
Lapaquellerie, Y., J. M. Jouanneau, N. Maillet \& C. Latouche, 1995. Pollution en cadmium dans les sédiments du Lot (France) et calcul du stock de polluant. Envir. Tech. 16: 1145-1154.

Lapaquellerie, Y., N. Maillet, J. M. Jouanneau, J. P. Coakley \& C. Latouche, 1996. Flux de matières en suspension et de cadmium dans le Lot. Hydroecol. Appl. 8: 173-191.

Latouche, C., 1988. La pollution en cadmium de l'Estuaire de la Gironde, Bull. Inst. Géol. Bassin d'Aquitaine 44: 15-21.

Latouche, C., 1992. La pollution par le cadmium des huitres sauvages de l'Estuaire de la Gironde. Origine. Mécanismes responsables de la fixation du cadmium. Ichtyophysiol. Acta 15: 139-152.

Lerman, A., 1979. Geochemical processes water and sediment environments. Wiley-Interscience Publication, John Wiley \& sons: 481 pp.

Maneux, E., F. E. Grousset, P. Buat-Ménard, G. Lavaux, P. Rimmelin \& Y. Lapaquellerie, 1998. High frequency variability of the wet deposition of anthropogenic heavy metals: the Arcachon Lagoon (SW france). Estuarine, Coastal and Shelf Science. (in press).

Martin, J. M. \& M. Whitfield, 1983. The significance of the river input of chemical elements to the oceans. In C. S. Wong, E. Boyle, K. W. Bruland, J. D. Burton \& E. D. Goldberg (eds) Trace metals in Sea Water. New-York: Plenum: 265-296.

Massio, J. C., 1976. Facteurs d'évolution des matières en suspension minérales et organiques dans les eaux du Lot. Thèse Université P. Sabatier, Toulouse: $135 \mathrm{pp}$

Meybeck, M., 1992. Etablissement des flux polluants. Rapport final, Agence de 1'Eau Adour-Garonne.

Meybeck, M., A. Pasco \& A. Ragu, 1994. Etablissement des flux polluants dans les rivières: pourquoi, comment et à quel prix. 4ème Rencontres de l'Agence Régionale pour l'Environnement. Provence-Alpes-Côte d'Azur. Colloque scientifique sur les charges polluantes véhiculées par les fleuves et les rivières en Méditerranée.Collection 1991-1992-1993.

Roux, M. \& F. Simonet, 1987. Pollutions accidentelles du Lot: Flux polluant. Revue de l'Agence de 1'Eau Adour-Garonne. 34: 7-9.

Trefry, J. H. \& B. J. Presley, 1976. Heavy metal transport from the Mississippi River to the Gulf of Mexico. In H. L. Windom \& R. A. Duce (eds), Marine Pollutant Transport, Mass: Lexington Books: $39-76$

Valenta, P., M. L. S. Simoes-Goncalves \& M. Sugawara, 1984. Voltametric studies on the speciation of $\mathrm{Cd}$ and $\mathrm{Zn}$ by amino acids in sea water. In C. J. M. Kramer \& J. C. Duinker (eds), Complexation of Trace Metals in Natural Water. Martinus Nijhoff Publishers: 357-365.

Van der Weijden, C. H. \& M. Middelburg, 1989. Hydrogeochemistry of the river Rhine. Wat. Res. 10: 1247-1266.

Webb, B. W., J. M. Phillips, D. E. Walling, I. G. Littlewood, C. Watts \& G. J. L. Leeks, 1997. Load estimation methodologies for British rivers and their relevance to the LOIS RACS (R) programme. Sci. Total Envir. 194/195: 379-389. 